Isabel A. Calvo ${ }^{1^{*}}$

\title{
Noncoding RNA in cancer
}

${ }^{1}$ Massachusetts General Hospital Cancer Center and Department of Medicine, Harvard Medical School, $13^{\text {th }}$ Street, Charlestown, MA 02129, USA and Centro de Investigación Médica Aplicada (CIMA) - Universidad de Navarra, Pío XII, 55 E-31008 Pamplona (Spain)

* Correspondence email: isabelcalvo83@gmail.com

\begin{abstract}
Non-coding RNAs (ncRNAs) are diverse classes of RNA molecules not translated into proteins, which possess intricate regulatory and structural functions. NcRNAs belong to a family of regulatory transcripts that affect every stage of gene expression, from transcription and mRNA stability to mRNA translation. Recent evidence has uncovered critical roles for noncoding RNAs in cancer pathogenesis. For example, variation of specific microRNAs has shown to drive tumorigenesis in human cancer cells and mouse models. Long noncoding RNAs (IncRNAs) have also been related to diverse cancer phenotypes and neurological disorders. NcRNAs are deeply involved in the regulation of key genes that are associated with cancer, representing a promising area for new therapies. This review focuses on ncRNAs, their role in cancer, and the translational implications of noncoding RNA research that may contribute to the development of innovative therapeutic solutions to treat cancer, and improve patients' quality of life and survival.
\end{abstract}

Keywords: noncoding RNA (ncRNA), IncRNA, miRNA, cancer.

The noncoding genome represents around $97 \%$ of the human genome. NcRNAs can be categorized into distinct classes, based on their biogenesis, size, and biologic function. Long noncoding RNAs (16000), small noncoding RNAs (7500) and pseudogenes (15000) belong to this imense group of genes. The noncoding genome is persistently transcribed. $85 \%$ represents transcribed genome versus silent genome (15\%). Long noncoding RNAs (IncRNAs) are ncRNAs bigger than 200nt, which are not translated and are seldom expressed. They also have tissue specific expression and lack of ORF and conservation.

Short regulatory ncRNAs ( $<200$ nucleotides) include miRNAs, siRNAs, and piwiassociated RNAs (piRNAs). piRNAs are produced by a long RNA, which is a RNA polymerase II (Pol II) transcript. MicroRNAs (miRNAs) are the best characterized class of short ncRNAs (19-24 nt), which are present in animals, plants, and algae (BARTEL 2009). The first miRNA, lin-4, was discovered in the early 1990s. Lin-4 and let-7 were described as regulators of developmental timing in the nematode (LEE et al. 1993; WIGHTMAN et al. 1993 ;REINHART et al. 2000). miRNAs are well conserved in both plants and animals, and are thought to be a vital and evolutionarily ancient component of gene regulation (PETERSON et al. 2009).

Long regulatory non-coding RNA (IncRNAs) (200-100,000 nucleotides) (GUTSCHNER and DIEDERICHS 2012; PONTING et al. 2009) contribute to the regulation of gene expression at various levels, such as chromatin modification, transcription and post-transcriptional processing. And are functional RNA molecules involved in diverse cellular processes: epigenetic regulation (Xist, H19, Anril, Terra, ecCEBP...), proteostasis (HULC, MEG3, GAS5, PANDA, HOTAIR...), stem cell pool (AKO28326, ES1, ES2,ES3, Linc-ROR,...), cell proliferation (MALAT1, ANRIL, SRA, UCA1, HEIH...), intercellular communication (17A, Lethe, THRIL, TUC339, LNC-IL7R...), and 
telomere stability (TERC, TERRA...) among others (GRAMMATIKAKIS et al. 2014). Human IncRNAs annotated by the GENCODE project comprise the largest public dataset containing 15,877 IncRNA genes, although it has been identified a huge number of new IncRNA genes (IYER et al. 2015).

Due to advances in sequencing technologies, a growing number of long noncoding RNAs (IncRNAs) have been identified, and many of them have shown to be key regulators of protein coding genes. Analyses of global transcriptome have shown that up to $70 \%$ of protein coding genes that have an antisense RNA can act as a key regulator of sense mRNA transcription (KATAYAMA et al. 2005). Moreover, dysregulation of IncRNAs is linked to various human diseases from neurodegeneration to cancer (WAPINSKI and CHANG 2011). A number of reports suggest that IncRNAs are critical in epigenetic regulation that can alter histone modifications in cis and trans (RINN and CHANG 2012; SABIN et al. 2013; JOH et al. 2014). A significant fraction ( 20\%) of IncRNAs can physically associate with the polycomb repressive complex 2 (PRC2), which suggests IncRNAs play an active role in chromatin modification and gene repression (KHALIL et al. 2009; GUTTMAN et al. 2011).

Implications of ncRNAs in cancer

Cancer is characterized by uncontrollable cell growth resulting from a complex multistep accumulation of sequential genetic alterations. Previously, it has been shown the role of RNA-protein interactions in the regulation of oncogenic and tumor suppressive genes. However, the precise functions of many individual ncRNAs are still an enigma (POLISENO et al. 2010; KALYANA-SUNDARAM et al. 2012). Although there is cumulative evidence that ncRNAs are essential for cell proliferation and survival under physiologic conditions, and their deregulation is linked to oncogenesis (see table 1 and 2) (KEUN et al. 2009; CALIN et al. 2007; SPIZzo et al. 2012; Ll et al. 2013).

To date, the role of miRNA in cancer has been far better characterized than IncRNAs, and their expression profiles can be used in the classification of human cancers (LU et al. 2005). miRNAs can act as tumor suppressors and oncogenes which are down- and up-regulated in cancer, respectively. One of the first oncogenic miRNA described was miR17-92 (see table 1) which has pleiotropic functions in the cell. miR17-92 is overexpressed in lung and colon cancer, lymphoma, multiple myeloma and medulloblastoma (MENDELL 2008), and its absence induces an increase of the proapoptotic protein Bim and inhibits the pro-B to pre-B cell development ( $\mathrm{HE}$ et al. 2005).

In contrast, miR15 and miR-16 are tumorsuppressive miRNAs by the induction of apoptosis of transformed cells and cell cycle regulation. Some studies demonstrated the relation of miR15 and miR16 to chronic lymphocytic leukemias (CALIN et al. 2002), epithelial malignancies and ovarian cancer (BHATTACHARYA et al. 2009). 
Table 1. Cancer-related miRNAs

\begin{tabular}{|c|c|c|}
\hline NAME & CANCER TYPE & FUNCTION \\
\hline miR 17-92 & lung and colon, lymphoma, multiple myeloma and medulloblastoma & oncogenic \\
\hline miR-21 & breast, lung, pancreatic and prostate, & oncogenic \\
\hline $\operatorname{miR}-10 b$ & breast and lung & oncogenic \\
\hline \multirow[t]{2}{*}{$\operatorname{miR}-22$} & gastric & oncogenic \\
\hline & hepatocellular, lung, colorectal, ovarian and breast & tumor supressive \\
\hline $\operatorname{miR}-373$ & breast & oncogenic \\
\hline $\operatorname{miR} 15-16$ & CLL (chronic lymphocytic leukaemia) & tumor supressive \\
\hline \multirow[t]{2}{*}{ Let-7 family } & pancreatic & oncogenic \\
\hline & breast, lung, hepatocellular, prostate,ovarian and neuroblastoma & tumor supressive \\
\hline $\operatorname{miR}-31$ & breast & tumor supressive \\
\hline $\operatorname{miR}-335$ & breast & tumor supressive \\
\hline \multirow[t]{2}{*}{ miR-34 } & breast, gastric and renal cell carcinoma & oncogenic \\
\hline & lung, pancreatic, colon and prostate & tumor supressive \\
\hline miR-26a & glioma & oncogenic \\
\hline miR-29 family & lung, breast, CLL & tumor supressive \\
\hline miR-101 & prostate and bladder & tumor supressive \\
\hline miR-124a family & breast, colorectal, ling, leukemia and lymphoma & tumor supressive \\
\hline $\operatorname{miR}-127$ & bladder & tumor supressive \\
\hline miR-143 and 145 & breast and colon & tumor supressive \\
\hline $\operatorname{miR}-148 \mathrm{a}$ & breast, colorectal, melanoma and lung & tumor supressive \\
\hline miR-155 & breast and lung cancer. B-cell lymphomas & oncogenic \\
\hline miR-200 family & breast and gastric & tumor supressive \\
\hline miR-221 and 222 & hepatocellular and thyroides & oncogenic \\
\hline
\end{tabular}

Table 1 also shows other miRNAs with oncogenic and tumor suppressive functions. In addition to cancer-associated miRNAs, Qiao and colleagues described the first evidence of the role of piRNAs in cancer (QIAO et al. 2002). Hiwi, Piwi family member, is overexpressed in seminomas but not in nonseminomas or in somatic tumors of the adult testis (QIAO et al. 2002). SnoRNAs are also involved in the beginning of the Prader-Willy syndrome (PWS), and are induced by the genetic loss of the 15q11-q13 locus (normally active only on the paternal allele). This site is characterized by several copies of the HBII85 snoRNA, whose loss seems to be correlated with the PWS phenotype, both in human and in mice (MOURTADA-MAARABOUNI et al. 2009).

Many IncRNAs were first characterized by their repressive functions, including ANRIL, HOTAIR, H19, KCNQ10T1, and (RINN et al.
2007; YAP et al. 2010; GIBB et al. 2011) (see table 2). These IncRNAs exert their repressive function by connection with histone-modifying or chromatin-remodeling protein complexes (PRENSNER and CHINNAIYAN 2011a). In addition, they can regulate the expression of some genes related with tumorigenesis (Luo et al. 2001; LUJAMBIO and ESTELLER 2009; MAES et al. 2010). For example, satellite repeats in heterochromatin are normally repressed and are highly expressed in multiple cancers (TING et al. 2011). Another IncRNA, HULC, has been shown to be overexpressed in hepatocellular carcinoma, in which may act as miRNA sponge, and in colorectal cancer. HULC is implicated in liver metastasis (MATOuK et al. 2007). These examples illustrate the possibility of the role of ncRNAs as biomarkers or therapeutic targets to cancer.

In summary, LncRNAs are implicated in multiple functions during cancer, such as 
development (RAO et al. 2017), sustainment of proliferative signaling (MEG3, SRA...), evasion of growth suppressors (ANRIL, GAS5...), induction of angiogenesis (MVIH, aHIF...), activation of invasion and metastasis (HULS, MALAT1...), resistance to cell death ( $b c / 2 / \operatorname{lgH}$ AS...) and enabling of replicative immortality (TERC, TERRA...) (RAo et al. 2017).

Over the last several years, approaches to demonstrate the important role of ncRNAs have been published. Similar observations have been also made using murine models. Some examples are described above:

(1) The Metastasis-Associated-in-Lung Adenocarcinoma -Transcript-1 (MALAT-1) is an ncRNA that is highly expressed in several tumor types. The overexpression and RNA interference (RNAi) approaches were used for the analysis of the biological functions of MALAT-1 RNA. In non-small cell lung cancer (NSCLC), MALAT-1 displays the strongest association with genes involved in cancer like cellular growth, movement, proliferation, signaling, and immune regulation (SCHMIDT et al. 2011).
(2) The overexpression of AK081227 mediated by the Mecp2 loss is associated with the downregulation of its host coding protein gene, the gamma-aminobutyric acid receptor subunit Rho 2 (Gabrr2). The transcriptional dysregulation of IncRNA upon Mecp2 loss contributes to the neurological phenotype of Rett syndrome and highlights the complex interaction between ncRNAs and coding-RNAs (PETAZZI et al. 2013).

(3) The knockdown of the antisense noncoding mitochondrial RNAs (ASncmtRNAs) generates a new murine noncoding mitochondrial RNAs (ncmtRNAs) model, which could be potent targets for melanoma therapy. This has been the first potential non-nuclear target for melanoma therapy (LoBOS-GONZALEZ et al. 2016).

Table 2. Cancer-related IncRNAs

\begin{tabular}{lll}
\hline NAME & CANCER & FUNCTION \\
\hline HOTAIR & breast, colorectal and hepatocellular & oncogenic \\
MALAT1 & breast, prostate, colon, liver and uterus & oncogenic \\
HULC & hepatocellular & oncogenic \\
ANRIL & breast, prostate and leukaemia & oncogenic \\
& coronary artery disease (CAD) and periodontitis (PD) & tumor supressive \\
H19 & bladder, lung, liver, breast, esophagus, colorectal and pancreatic & oncogenic \\
PCA3 & prostate & oncogenic \\
PCAT-1 & prostate & oncogenic \\
uc.73a & leukemia & oncogenic \\
PCGEM1 & prostate & oncogenic \\
TUC338 & hepatocellular & oncogenic \\
UCA1/CUDR & bladder, colon, cervix, lung, thyroid, liver, breast, esophagus, stomach & oncogenic \\
Spry4-it1 & melanoma & oncogenic \\
BC200 & breats, cervix, esophagus, lung, ovary, parotid, tongue & oncogenic \\
MEG3 & brain & tumor supressive \\
SRA & breast, uterus, ovary & tumor supressive \\
GAS5 & breast and renal cell carcinoma & tumor supressive \\
PTENP1 & prostate, colon & tumor supressive \\
Linc-p21 & lung (mouse models) & tumor supressive \\
\hline
\end{tabular}




\section{1.- ncRNAs-diagnostic tools}

Biomarkers are biological indicators of disease states used to classify cancer types or subtypes (HUI et al. 2011). Novel cancer diagnostics, prognostics and anti-cancer approaches based upon ncRNA biology are quickly developing during the last years (CALIN and CROCE 2006; SPIZZO et al. 2012). Focusing on latest reports, miRNA expression has been used to distinguish between acute lymphoblastic leukemia and acute myeloid leukemia (AML) (Mı et al. 2007). Moreover, several groups predicted the outcome in solid tumors using miRNA expression such as colon adenocarcinomas (SCHETTER et al. 2008), squamous cell lung cancer (RAPONI et al. 2009) and hematological malignancies including $A M L$ (MARCUCCl et al. 2008). In addition, it has been described the correlation between circulating miRNA levels and the response to a given anticancer agent (HUI et al. 2009). The best example is miR-21, which is upregulated in human cancers and the levels of circulating miR-21 were higher in patients with hormone-refractory prostate cancer, whose disease was resistant to docetaxel-based chemotherapy, in comparison with patients who had chemo sensitive disease (ZHANG et al. 2011).

The study of IncRNAs is a fast growing field of research. HOTAIR can be a potential biomarker for the existence of lymph node metastasis in hepatocellular carcinoma (HCC) (GENG et al. 2011). HULC (PANZITT et al. 2007) or other InCRNA, MALAT1 (LAl et al. 2012) can be used as a prognostic markers. One of the IncRNAs utilized in a clinical test is PCA3 (prostate cancer associated), which can be detected in urine samples obtained after a prostatic massage (MARKs et al. 2007). The detection of both miRNAs and IncRNAs in body fluids, such as blood or urine, and its use as non-invasive cancer biomarkers is an active area of research due to their high stability and resistance to storage and handling (TINZL et al. 2004; MitCHELL et al. 2008).

\section{2.- ncRNAs in cancer therapy}

As many miRNA and IncRNA are deregulated in cancer, many researchers now focus on their role as therapeutic targets (AL OLABY and AZZAZY 2011). miRNA therapy is being used to down-regulate or block the function of oncogenic miRNAs or up-regulate their tumor-suppressive function. There are several approaches to control oncogenic miRNA expression: by introducing mRNAs targeting specific miRNAs or by using antisense singlestranded oligonucleotides complementary to miRNA, which acts as miRNA sponges and miRNA antagonists, respectively (Merikallio et al. 2011; Diallo et al. 2011); BRODERICK et al. 2011). Alternatively, new techniques to re-express miRNAs with tumor suppressor roles are constantly emerging, as the administration of synthetic miRNA becomes a common therapy (TRANG et al. 2010). It has also been reported the successful systemic delivery of miRNAs as anti-cancer approaches in preclinical models using liposomes viral vectors (КOTA et al. 2009; RAl et al. 2011) and nanoparticles (SU et al. 2011). A better understanding of the molecular mechanisms of IncRNAs in cancer might lead to development of more effective cancer therapies in the near future. Recently, it has been published the role of 7SL ncRNA in the treatment of cancers. This function could be related with tumor suppressor p53, which suggest that targeting 7SL may be effective in the treatment of cancers with reduced p53 levels (ABDELMOHSEN et al. 2014). A more recent report demonstrated the link between miR-155 and SMARCA4 expression levels in theprognosis of patients with lung tumors. This seems to be be due to oncogenic properties of miR-155 in lung 
cancer by its role inhibiting SMARCA4 (COIRA et al. 2015).

NcRNAs can also be related to chemo resistance by damaging the response through cell cycle arrest, enhanced DNA damage repair and inhibition of apoptosis (LIPOVICH et al. 2010; GoldMAN 2003; HARRIES 2012). Several IncRNAs in cancer can upregulate drug resistance gene (CUDR) and antagonize the apoptotic effect of cisplatin in bladder cancer cells (D'ADDA DI FAGAGNA 2008). Moreover, the growth arrest-specific 5 IncRNA Gas5, which contributes to glucocorticoid resistance, is associated with therapeutic resistance (YANG et al. 2012) (KINO et al. 2010). PANDA is increased in a subset of breast cancer cells that contributes to anthracycline resistance, a crucial component of breast cancer chemotherapy (SOTILLO and THOMASTIKHONENKO 2011). They are also many p53regulated IncRNAs, which are induced in response to DNA damage and promote chemo resistance (AMIT and HOCHBERG 2010). HULC InCRNA may also act as an endogenous sponge to reduce miRNA levels and inhibit their functional activity (PANZITT et al. 2007). This functional and structural innovation of IncRNAs offers potential as anticancer therapeutics that can prevent the emergence of drug resistance commonly seen with current agents (MALEK et al. 2014).

\section{Conclusions}

Highly relevant functions of ncRNAs have been recently demonstrated. Based on recent discoveries in genome editing in simple organisms, similar technologies might soon become available to the study of mammalian systems (HOCKEMEYER et al. 2011); (WANG et al. 2013); (JINEK et al. 2012). A key area of research would be 1) to link IncRNA-miRNA interactions and human diseases, and 2) to functionally characterize other IncRNAs (e.g., very long IncRNAs, pseudo genes, antisense RNAs) and other small RNAs (e.g., piRNAs, siRNAs, snoRNAs). A stronger collaboration between molecular biologists, bioinformaticians and systems biologists will help identifying the critical nodes in these complex systems and their implications in cancer. This synergic work may help providing novel potential drug candidates that can be translated into the clinic.

\section{Acknowledgements}

I would like to thank Richard Inho Joh and Joao Duarte for their contribution to this manuscript. This work was supported by Beatriu de Pinos (Generalitat de Catalunya) and Juan de la Cierva postdoctoral fellowships to IAC.

\section{References (Tables)}

(CALIN et al. 2012)

(PASMANT et al. 2007)

(DAvalos and Esteller 2010; PrensNer and

CHINNAIYAN 2011b)

(HAUPTMAN and GLAVAC 2013)

(BOCHENEK et al. 2013)

(TANG et al. 2015)

\section{References}

\section{References}

Abdelmohsen, K., A. C. Panda, M. J. Kang, R. Guo, J. Kim et al., 2014 7SL RNA represses p53 translation by competing with HuR. Nucleic Acids Res 42: 1009910111.https://doi.org/10.1093/nar/gku686 PMid:25123665 PMCid:PMC4150789

Al Olaby, R. R., and H. M. Azzazy, 2011 Hepatitis $C$ virus RNA assays: current and emerging technologies and their clinical 
applications. Expert Rev Mol Diagn 11: 53-

64. https://doi.org/10.1586/erm.10.101 PMid:21171921

Amit, D., and A. Hochberg, 2010 Development of targeted therapy for bladder cancer mediated by a double promoter plasmid expressing diphtheria toxin under the control of H19 and IGF2-P4 regulatory sequences. J Transl Med 8: 134. https://doi.org/10.1186/1479-5876-8-134

PMid:21162716 PMCid:PMC3016259

Bartel, D. P., 2009 MicroRNAs: target recognition and regulatory functions. Cell 136:

215-233.

https://doi.org/10.1016/j.cell.2009.01.002

PMid:19167326 PMCid:PMC3794896

Bhattacharya, R., A. M. Gonzalez, P. J. Debiase, H. E. Trejo, R. D. Goldman et al., 2009 Recruitment of vimentin to the cell surface by beta3 integrin and plectin mediates adhesion strength. J Cell Sci 122: 1390-1400.

https://doi.org/10.1242/jcs.043042

PMid:19366731 PMCid:PMC2721003

Bochenek, G., R. Hasler, N. E. El Mokhtari, I. R. Konig, B. G. Loos et al., 2013 The large non-coding RNA ANRIL, which is associated with atherosclerosis, periodontitis and several forms of cancer, regulates ADIPOR1, VAMP3 and C11ORF10. Hum Mol Genet 22: 4516-4527. https://doi.org/10.1093/hmg/ddt299

PMid:23813974

Broderick, J. A., W. E. Salomon, S. P. Ryder, N. Aronin and P. D. Zamore, 2011 Argonaute protein identity and pairing geometry determine cooperativity in mammalian RNA silencing. RNA 17: 18581869. https://doi.org/10.1261/rna.2778911 PMid:21878547 PMCid:PMC3185918

Calin, G. A., and C. M. Croce, 2006 MicroRNA signatures in human cancers. Nat Rev Cancer 6: 857-866. https://doi.org/10.1038/nrc1997 PMid:17060945
Calin, G. A., C. D. Dumitru, M. Shimizu, R. Bichi, S. Zupo et al., 2002 Frequent deletions and down-regulation of microRNA genes miR15 and miR16 at 13q14 in chronic lymphocytic leukemia. Proc Natl Acad Sci U S A 99: 1552415529.https://doi.org/10.1073/pnas.24260 6799 PMid:12434020 PMCid:PMC137750

Calin, G. A., C. G. Liu, M. Ferracin, T. Hyslop, R. Spizzo et al., 2007 Ultraconserved regions encoding ncRNAs are altered in human leukemias and carcinomas. Cancer Cell 12: 215-229. https://doi.org/10.1016/j.ccr.2007.07.027 PMid:17785203

Calin, R., L. Paris, A. Simon, G. Peytavin, M. Wirden et al., 2012 Dual raltegravir/etravirine combination in virologically suppressed HIV-1-infected patients on antiretroviral therapy. Antivir Ther 17: 1601-1604. https://doi.org/10.3851/IMP2344

PMid:22941896

Coira, I. F., E. E. Rufino-Palomares, O. A. Romero, P. Peinado, C. Metheetrairut et al., 2015 Expression inactivation of SMARCA4 by microRNAs in lung tumors. Hum Mol Genet 24: 1400-1409. https://doi.org/10.1093/hmg/ddu554

PMid:25355421 PMCid:PMC4321447

d'Adda di Fagagna, F., 2008 Living on a break: cellular senescence as a DNAdamage response. Nat Rev Cancer 8: 512522.

https://doi.org/10.1038/nrc2440

PMid:18574463

Davalos, V., and M. Esteller, 2010 MicroRNAs and cancer epigenetics: a macrorevolution. Curr Opin Oncol 22: 3545.

https://doi.org/10.1097/CCO.0b013e32833 3dcbb PMid:19907325

Diallo, D. A., A. Guindo, A. Dorie, N. Djibo, E. Algiman et al., 2011 [Human parvovirus B19 infection in sickle cell anemia patient in Mali: a case-control study]. Arch Pediatr 
18:

962-965.

https://doi.org/10.1016/j.arcped.2011.06.0 19 PMid:21803552

Geng, Y. J., S. L. Xie, Q. Li, J. Ma and G. Y. Wang, 2011 Large intervening non-coding RNA HOTAIR is associated with hepatocellular carcinoma progression. J Int Med Res 39: 2119-2128. https://doi.org/10.1177/147323001103900 608 PMid:22289527

Gibb, E. A., E. A. Vucic, K. S. Enfield, G. L. Stewart, K. M. Lonergan et al., 2011 Human cancer long non-coding RNA transcriptomes. PLoS One 6: e25915. https://doi.org/10.1371/journal.pone.0025 915 PMid:21991387 PMCid:PMC3185064

Goldman, B., 2003 Multidrug resistance: can new drugs help chemotherapy score against cancer? J Natl Cancer Inst 95: 255257. https://doi.org/10.1093/inci/95.4.255 PMid:12591977

Grammatikakis, I., A. C. Panda, K. Abdelmohsen and M. Gorospe, 2014 Long noncoding RNAs(IncRNAs) and the molecular hallmarks of aging. Aging (Albany NY) 6: 992-1009. https://doi.org/10.18632/aging.100710 PMid:25543668 PMCid:PMC4298369

Gutschner, T., M. Baas and S. Diederichs, 2011 Noncoding RNA gene silencing through genomic integration of RNA destabilizing elements using zinc finger nucleases. Genome Res 21: 1944-1954. https://doi.org/10.1101/gr.122358.111

PMid:21844124 PMCid:PMC3205578

Gutschner, T., and S. Diederichs, 2012 The hallmarks of cancer: a long non-coding RNA point of view. RNA biology 9: 703-719. https://doi.org/10.4161/rna.20481

PMid:22664915 PMCid:PMC3495743

Guttman, M., J. Donaghey, B. W. Carey, M. Garber, J. K. Grenier et al., 2011 lincRNAs act in the circuitry controlling pluripotency and differentiation. Nature 477: 295-300. https://doi.org/10.1038/nature10398
PMid:21874018 PMCid:PMC3175327

Harries, L. W., 2012 Long non-coding RNAs and human disease. Biochem Soc Trans 40: 902-906.

https://doi.org/10.1042/BST20120020 PMid:22817756

Hauptman, N., and D. Glavac, 2013 MicroRNAs and long non-coding RNAs: prospects in diagnostics and therapy of cancer. Radiol Oncol 47: 311-318. https://doi.org/10.2478/raon-2013-0062

PMid:24294175 PMCid:PMC3814275

He, L., J. M. Thomson, M. T. Hemann, E. Hernando-Monge, D. Mu et al., 2005 A microRNA polycistron as a potential human oncogene. Nature 435: 828-833. https://doi.org/10.1038/nature03552

PMid:15944707 PMCid:PMC4599349

Hockemeyer, D., H. Wang, S. Kiani, C. S. Lai, Q. Gao et al., 2011 Genetic engineering of human pluripotent cells using TALE nucleases. Nat Biotechnol 29: 731-734. https://doi.org/10.1038/nbt.1927

PMid:21738127 PMCid:PMC3152587

Hui, A., C. How, E. Ito and F. F. Liu, 2011 Micro-RNAs as diagnostic or prognostic markers in human epithelial malignancies. BMC $\quad$ Cancer 11: 500. https://doi.org/10.1186/1471-2407-11-500 PMid:22128797 PMCid:PMC3260334

Hui, A. B., W. Shi, P. C. Boutros, N. Miller, M. Pintilie et al., 2009 Robust global microRNA profiling with formalin-fixed paraffinembedded breast cancer tissues. Lab Invest 89:

597-606.

https://doi.org/10.1038/labinvest.2009.12 https://doi.org/10.1038/labinvest.2009.46 PMid:19290006

lyer, M. K., Y. S. Niknafs, R. Malik, U. Singhal, A. Sahu et al., 2015 The landscape of long noncoding RNAs in the human transcriptome. Nat Genet 47: 199-208. https://doi.org/10.1038/ng.3192

PMid:25599403 PMCid:PMC4417758

Jinek, M., K. Chylinski, I. Fonfara, M. Hauer, 
J. A. Doudna et al., 2012 A programmable dual-RNA-guided DNA endonuclease in adaptive bacterial immunity. Science 337 : 816-821.

https://doi.org/10.1126/science.1225829

PMid:22745249

Joh, R. I., C. M. Palmieri, I. T. Hill and M. Motamedi, 2014 Regulation of histone methylation by noncoding RNAs. Biochim Biophys Acta 1839: 1385-1394. https://doi.org/10.1016/j.bbagrm.2014.06. $\underline{006}$

PMid:24954181 PMCid:PMC4258512

Kalyana-Sundaram, S., C. Kumar-Sinha, S. Shankar, D. R. Robinson, Y. M. Wu et al., 2012 Expressed pseudogenes in the transcriptional landscape of human cancers. Cell 149: 16221634.https://doi.org/10.1016/i.cell.2012.0 4.041 PMid:22726445 PMCid:PMC3597446

Katayama, S., Y. Tomaru, T. Kasukawa, K. Waki, M. Nakanishi et al., 2005 Antisense transcription in the mammalian transcriptome. Science 309: 1564-1566. https://doi.org/10.1126/science.1112009 PMid:16141073

Keun, H. C., J. Sidhu, D. Pchejetski, J. S. Lewis, H. Marconell et al., 2009 Serum molecular signatures of weight change during early breast cancer chemotherapy. Clin Cancer Res 15: 6716-6723. https://doi.org/10.1158/1078-0432.CCR09-1452 PMid:19861449

Khalil, A. M., M. Guttman, M. Huarte, M. Garber, A. Raj et al., 2009 Many human large intergenic noncoding RNAs associate with chromatin-modifying complexes and affect gene expression. Proc Natl Acad Sci U S A 106: 11667-11672. https://doi.org/10.1073/pnas.0904715106 PMid:19571010 PMCid:PMC2704857

Kino, T., D. E. Hurt, T. Ichijo, N. Nader and G. P. Chrousos, 2010 Noncoding RNA gas 5 is a growth arrest- and starvationassociated repressor of the glucocorticoid receptor. Sci Signal 3: ra8. https://doi.org/10.1126/scisignal.2000568 PMid:20124551 PMCid:PMC2819218

Kota, J., R. R. Chivukula, K. A. O'Donnell, E. A. Wentzel, C. L. Montgomery et al., 2009 Therapeutic microRNA delivery suppresses tumorigenesis in a murine liver cancer model. Cell 137: 1005-1017. https://doi.org/10.1016/i.cell.2009.04.021 PMid:19524505 PMCid:PMC2722880

Lai, M. C., Z. Yang, L. Zhou, Q. Q. Zhu, H. Y. Xie et al., 2012 Long non-coding RNA MALAT-1 overexpression predicts tumor recurrence of hepatocellular carcinoma after liver transplantation. Med Oncol 29: 1810-1816.

https://doi.org/10.1007/s12032-011-0004z PMid:21678027

Lee, R. C., R. L. Feinbaum and V. Ambros, 1993 The C. elegans heterochronic gene lin-4 encodes small RNAs with antisense complementarity to lin-14. Cell 75: 843$854 . \quad$ https://doi.org/10.1016/00928674(93)90529-Y

Li, X., Z. Wu, X. Fu and W. Han, 2013 Long Noncoding RNAs: Insights from Biological Features and Functions to Diseases. Med

Res Rev 33: 517-553. https://doi.org/10.1002/med.21254

PMid:22318902

Lipovich, L., R. Johnson and C. Y. Lin, 2010 MacroRNA underdogs in a microRNA world: evolutionary, regulatory, and biomedical significance of mammalian long non-protein-coding RNA. Biochim Biophys Acta 1799: 597-615. https://doi.org/10.1016/j.bbagrm.2010.10. 001 PMid:20951849

Lobos-Gonzalez, L., V. Silva, M. Araya, F. Restovic, J. Echenique et al., 2016 Targeting antisense mitochondrial ncRNAs inhibits murine melanoma tumor growth and metastasis through reduction in survival and invasion factors. Oncotarget 7: 5833158350. https://doi.org/10.18632/oncotarget.1111 o PMid:27507060 PMCid:PMC5295434 
Lu, J., G. Getz, E. A. Miska, E. AlvarezSaavedra, J. Lamb et al., 2005 MicroRNA expression profiles classify human cancers. Nature 435: 834-838. https://doi.org/10.1038/nature03702

PMid:15944708

Lujambio, A., and M. Esteller, 2009 How epigenetics can explain human metastasis: a new role for microRNAs. Cell Cycle 8: 377382. https://doi.org/10.4161/cc.8.3.7526 PMid:19177007

Luo, J., D. J. Duggan, Y. Chen, J. Sauvageot, C. M. Ewing et al., 2001 Human prostate cancer and benign prostatic hyperplasia: molecular dissection by gene expression profiling. Cancer Res 61: 4683-4688. PMid:11406537

Maes, O. C., H. M. Schipper, G. Chong, H. M. Chertkow and E. Wang, 2010 A GSTM3 polymorphism associated with an etiopathogenetic mechanism in Alzheimer disease. Neurobiol Aging 31: 34-45. https://doi.org/10.1016/j.neurobiolaging.2 008.03.007 PMid:18423940

Malek, E., S. Jagannathan and J. J. Driscoll, 2014 Correlation of long non-coding RNA expression with metastasis, drug resistance and clinical outcome in cancer. Oncotarget 5: 8027-8038. https://doi.org/10.18632/oncotarget.2469 PMid:25275300 PMCid:PMC4226665

Marcucci, G., M. D. Radmacher, K. Maharry, K. Mrozek, A. S. Ruppert et al., 2008 MicroRNA expression in cytogenetically normal acute myeloid leukemia. N Engl J Med 358: 1919-1928. https://doi.org/10.1056/NEJMoa074256 PMid:18450603

Marks, L. S., Y. Fradet, I. L. Deras, A. Blase, J. Mathis et al., 2007 PCA3 molecular urine assay for prostate cancer in men undergoing repeat biopsy. Urology 69: 532535.

https://doi.org/10.1016/i.urology.2006.12. 014 PMid:17382159
Matouk, I. J., N. DeGroot, S. Mezan, S. Ayesh, R. Abu-lail et al., 2007 The H19 noncoding RNA is essential for human tumor growth. PLoS One 2: e845. https://doi.org/10.1371/journal.pone.0000 845PMid:17786216 PMCid:PMC1959184

Mendell, J. T., 2008 miRiad roles for the miR-17-92 cluster in development and disease. Cell 133: 217-222. https://doi.org/10.1016/i.cell.2008.04.001 PMid:18423194 PMCid:PMC2732113

Merikallio, H., R. Kaarteenaho, P. Paakko, S. Lehtonen, P. Hirvikoski et al., 2011 Impact of smoking on the expression of claudins in lung carcinoma. Eur J Cancer 47: 620-630. https://doi.org/10.1016/i.ejca.2010.10.017 PMid:21106366

Mi, S., J. Lu, M. Sun, Z. Li, H. Zhang et al., 2007 MicroRNA expression signatures accurately discriminate acute lymphoblastic leukemia from acute myeloid leukemia. Proc Natl Acad Sci U S A 104: 19971-19976. https://doi.org/10.1073/pnas.0709313104 PMid:18056805 PMCid:PMC2148407

Mitchell, P. S., R. K. Parkin, E. M. Kroh, B. R. Fritz, S. K. Wyman et al., 2008 Circulating microRNAs as stable blood-based markers for cancer detection. Proc Natl Acad Sci U S A 105: 10513-10518. https://doi.org/10.1073/pnas.0804549105 PMid:18663219 PMCid:PMC2492472

Mourtada-Maarabouni, M., M. R. Pickard, V. L. Hedge, F. Farzaneh and G. T. Williams, 2009 GAS5, a non-protein-coding RNA, controls apoptosis and is downregulated in breast cancer. Oncogene 28: 195-208. https://doi.org/10.1038/onc.2008.373 PMid:18836484

Panzitt, K., M. M. Tschernatsch, C. Guelly, T. Moustafa, M. Stradner et al., 2007 Characterization of HULC, a novel gene with striking up-regulation in hepatocellular carcinoma, as noncoding RNA. Gastroenterology 132: 330-342. https://doi.org/10.1053/i.gastro.2006.08.0 
26 PMid:17241883

Pasmant, E., I. Laurendeau, D. Heron, M. Vidaud, D. Vidaud et al., 2007 Characterization of a germ-line deletion, including the entire INK4/ARF locus, in a melanoma-neural system tumor family: identification of ANRIL, an antisense noncoding RNA whose expression coclusters with ARF. Cancer Res 67: 3963$3969 . \quad$ https://doi.org/10.1158/00085472.CAN-06-2004 PMid:17440112

Petazzi, P., J. Sandoval, K. Szczesna, O. C. Jorge, L. Roa et al., 2013 Dysregulation of the long non-coding RNA transcriptome in a Rett syndrome mouse model. RNA Biol 10:

1197-1203.

https://doi.org/10.4161/rna.24286

PMid:23611944 PMCid:PMC3849168

Peterson, K. J., M. R. Dietrich and M. A. McPeek, 2009 MicroRNAs and metazoan macroevolution: insights into canalization, complexity, and the Cambrian explosion. Bioessays 31: 736-747. https://doi.org/10.1002/bies.200900033

PMid:19472371

Poliseno, L., L. Salmena, J. Zhang, B. Carver, W. J. Haveman et al., 2010 A codingindependent function of gene and pseudogene mRNAs regulates tumour biology. Nature 465: 1033-1038. https://doi.org/10.1038/nature09144

PMid:20577206 PMCid:PMC3206313

Ponting, C. P., P. L. Oliver and W. Reik, 2009 Evolution and functions of long noncoding RNAs. Cell 136: 629-641. https://doi.org/10.1016/j.cell.2009.02.006 PMid:19239885

Prensner, J. R., and A. M. Chinnaiyan, 2011a The emergence of IncRNAs in cancer biology. Cancer Discov 1: 391-407. https://doi.org/10.1158/2159-8290.CD-110209 PMid:22096659 PMCid:PMC3215093

Prensner, J. R., and A. M. Chinnaiyan, 2011b Metabolism unhinged: IDH mutations in cancer. Nat Med 17: 291-293. https://doi.org/10.1038/nm0311-291

PMid:21383741

Qiao, D., A. M. Zeeman, W. Deng, L. H. Looijenga and H. Lin, 2002 Molecular characterization of hiwi, a human member of the piwi gene family whose overexpression is correlated to seminomas. Oncogene 21: 3988-3999. https://doi.org/10.1038/sj.onc.1205505 PMid:12037681

Rai, K., N. Takigawa, S. Ito, H. Kashihara, E. Ichihara et al., 2011 Liposomal delivery of MicroRNA-7-expressing plasmid overcomes epidermal growth factor receptor tyrosine kinase inhibitor-resistance in lung cancer cells. Mol Cancer Ther 10: 1720-1727. https://doi.org/10.1158/1535-7163.MCT11-0220 PMid:21712475

Rao, A., T. Rajkumar and S. Mani, 2017 Perspectives of long non-coding RNAs in cancer. Mol Biol Rep 44: 203-218. https://doi.org/10.1007/s11033-017-41036 PMid:28391434

Raponi, M., L. Dossey, T. Jatkoe, X. Wu, G. Chen et al., 2009 MicroRNA classifiers for predicting prognosis of squamous cell lung cancer. Cancer Res 69: 5776-5783. https://doi.org/10.1158/0008-5472.CAN09-0587 PMid:19584273

Reinhart, B. J., F. J. Slack, M. Basson, A. E. Pasquinelli, J. C. Bettinger et al., 2000 The 21-nucleotide let-7 RNA regulates developmental timing in Caenorhabditis elegans. Nature 403: 901-906. https://doi.org/10.1038/35002607 PMid:10706289

Rinn, J. L., and H. Y. Chang, 2012 Genome regulation by long noncoding RNAs. Annu Rev Biochem 81: 145-166. https://doi.org/10.1146/annurev-biochem051410-092902

PMid:22663078 PMCid:PMC3858397

Rinn, J. L., M. Kertesz, J. K. Wang, S. L. Squazzo, X. Xu et al., 2007 Functional demarcation of active and silent chromatin 
domains in human HOX loci by noncoding RNAs. Cell 129: 13111323.https://doi.org/10.1016/j.cell.2007.0 5.022 PMid:17604720 PMCid:PMC2084369

Sabin, L. R., M. J. Delas and G. J. Hannon, 2013 Dogma derailed: the many influences of RNA on the genome. Mol Cell 49: 783794.

https://doi.org/10.1016/j.molcel.2013.02.0 10 PMid:23473599 PMCid:PMC3825098

Schetter, A. J., S. Y. Leung, J. J. Sohn, K. A. Zanetti, E. D. Bowman et al., 2008 MicroRNA expression profiles associated with prognosis and therapeutic outcome in colon adenocarcinoma. JAMA 299: 425436.

https://doi.org/10.1001/jama.299.4.425PM id:18230780 PMCid:PMC2614237

Schmidt, L. H., T. Spieker, S. Koschmieder, S. Schaffers, J. Humberg et al., 2011 The long noncoding MALAT-1 RNA indicates a poor prognosis in non-small cell lung cancer and induces migration and tumor growth. J Thorac Oncol 6: 1984-1992. https://doi.org/10.1097/JTO.0b013e31823 07eac PMid:22088988

Sotillo, E., and A. Thomas-Tikhonenko, 2011 Shielding the messenger (RNA): microRNA-based anticancer therapies. Pharmacol Ther 131: 18-32. https://doi.org/10.1016/i.pharmthera.2011 .04 .006 PMid:21514318 PMCid:PMC3124007

Spizzo, R., M. I. Almeida, A. Colombatti and G. A. Calin, 2012 Long non-coding RNAs and cancer: a new frontier of translational research? Oncogene 31: 4577-4587. https://doi.org/10.1038/onc.2011.621

PMid:22266873 PMCid:PMC3433647

Su, J., H. Baigude, J. McCarroll and T. M. Rana, 2011 Silencing microRNA by interfering nanoparticles in mice. Nucleic Acids $\quad$ Res 39: e38. https://doi.org/10.1093/nar/gkq1307 PMid:21212128 PMCid:PMC3064800
Tang, Y., Y. Wang, Q. Chen, N. Qiu, Y. Zhao et al., 2015 MiR-223 inhibited cell metastasis of human cervical cancer by modulating epithelial-mesenchymal transition. Int J Clin Exp Pathol 8: 1122411229.

PMid:26617846 PMCid:PMC4637661

Ting, D. T., D. Lipson, S. Paul, B. W. Brannigan, S. Akhavanfard et al., 2011 Aberrant overexpression of satellite repeats in pancreatic and other epithelial cancers. Science 331: 593-596. https://doi.org/10.1126/science.1200801 PMid:21233348 PMCid:PMC3701432

Tinzl, M., M. Marberger, S. Horvath and C. Chypre, 2004 DD3PCA3 RNA analysis in urine--a new perspective for detecting prostate cancer. Eur Urol 46: 182-186; discussion 187. https://doi.org/10.1016/j.eururo.2004.06.0 04 PMid:15245811

Trang, P., P. P. Medina, J. F. Wiggins, L. Ruffino, K. Kelnar et al., 2010 Regression of murine lung tumors by the let-7 microRNA. Oncogene 29: 1580-1587. https://doi.org/10.1038/onc.2009.445 PMid:19966857 PMCid:PMC2841713

Wang, J., Y. Guo, H. Chu, Y. Guan, J. Bi et al., 2013 Multiple functions of the RNAbinding protein HuR in cancer progression, treatment responses and prognosis. Int J Mol Sci 14: 10015-10041. https://doi.org/10.3390/ijms140510015 PMid:23665903 PMCid:PMC3676826

Wapinski, O., and H. Y. Chang, 2011 Long noncoding RNAs and human disease. Trends Cell Biol 21: 354-361. https://doi.org/10.1016/i.tcb.2011.04.001 https://doi.org/10.1016/j.tcb.2011.08.004 PMid:21550244

Wightman, B., I. Ha and G. Ruvkun, 1993 Posttranscriptional regulation of the heterochronic gene lin-14 by lin- 4 mediates temporal pattern formation in C. elegans. Cell 75: 855-862. https://doi.org/10.1016/0092- 


\section{4(93)90530-4}

Yang, C., X. Li, Y. Wang, L. Zhao and W. Chen, 2012 Long non-coding RNA UCA1 regulated cell cycle distribution via CREB through $\mathrm{PI3}-\mathrm{K}$ dependent pathway in bladder carcinoma cells. Gene 496: 8-16. https://doi.org/10.1016/i.gene.2012.01.01 2 PMid:22285928

Yap, K. L., S. Li, A. M. Munoz-Cabello, S. Raguz, L. Zeng et al., 2010 Molecular interplay of the noncoding RNA ANRIL and methylated histone $\mathrm{H} 3$ lysine 27 by polycomb CBX7 in transcriptional silencing of INK4a. Mol Cell 38: 662-674. https://doi.org/10.1016/j.molcel.2010.03.0 21 PMid:20541999 PMCid:PMC2886305

Zhang, H. L., L. F. Yang, Y. Zhu, X. D. Yao, S. L. Zhang et al., 2011 Serum miRNA-21: elevated levels in patients with metastatic hormone-refractory prostate cancer and potential predictive factor for the efficacy of docetaxel-based chemotherapy. Prostate 71: 326-331. https://doi.org/10.1002/pros.21246

PMid:20842666 